\title{
PEMETAAN DAN ABLASI PADA TAKIKARDIA VENTRIKEL AKIBAT PARUT
}

\author{
Loretta C. Wangko \\ Edmond L. Jim
}

\author{
Bagian Ilmu Penyakit Jantung dan Pembuluh Darah \\ Fakultas Kedokteran Universitas Sam Ratulangi Manado \\ Email: lorettawangko@yahoo.com
}

\begin{abstract}
Better understanding of the pathophysiology of ventricular tachycardia (VT) and techniques of mapping as well as ablation leads to higher succes and lower complication rates in the management of patients with VT. Mapping for identification the potential areas for ablation depends on the basic mechanisms of VTs. There are several mapping techniques; each has its own benefit and limitation. The usage of several mapping techniques together shows a higher succes rate. Activation mapping and pace mapping are very useful in focal VT mechanism meanwhile substrate mapping (with or without pace mapping) and entrainment mapping are used for reentrant VT mechanism. Nowadays, catheter ablation is an important option for VT cases with ineffective ICD and medication or intolerance, albeit, there is still no complete agreement for the best recommended mapping strategy and ablation techniques for scar-related VT, so far.
\end{abstract}

Keywords: ventricular tachycardia, scar, mapping, ablation

\begin{abstract}
Abstrak: Adanya kemajuan pesat baik dalam pemahaman mekanisme patofisiologi takikardia ventrikel (TV) maupun tehnik pemetaan dan ablasi memberikan keberhasilan yang lebih tinggi dan komplikasi yang lebih rendah pada penanganan pasien dengan TV. Pemetaan yang mengidentifikasi area berpotensi untuk dilakukan ablasi bergantung pada mekanisme mendasari terjadinya TV. Terdapat beberapa teknik pemetaan yang dapat digunakan dengan keunggulan dan limitasi masing-masing. Penggunaan beberapa teknik pemetaan bersamasama dapat dilakukan dengan tingkat keberhasilan yang lebih tinggi. Pemetaan aktivasi dan pemetaan langkah sangat bermanfaat pada mekanisme TV fokal sedangkan pemetaan substrat (dengan atau tanpa pemetaan langkah) dan pemetaan entrainment digunakan untuk mekanisme TV reentrant. Ablasi kateter merupakan pilihan utama untuk kasus TV akibat parut dengan penggunaan ICD dan medikasi yang tidak efektif atau intoleransi namun sampai saat ini belum terdapat rekomendasi yang pasti mengenai strategi pemetaan dan teknik ablasi yang terbaik untuk TV akibat parut.
\end{abstract}

Kata kunci: takikardia ventrikel, parut, pemetaan, ablasi

Dalam keadaan normal, jantung berdenyut sekitar 60-100 kali per menit dimana atria berkontraksi terlebih dahulu disusul oleh ventrikel secara sinkron. Pada takikardia ventrikel (TV), ventrikel berdenyut 120300 kali per menit dan tidak terkoordinasi lagi dengan atria. Bila denyut jantung melebihi 300 kali per menit dan tidak terkoordinasi secara total, disebut fibrilasi ventrikel yang menyebabkan sudden cardiac death (Gambar 1). Diperkirakan kejadian sudden cardiac death sekitar 450.000 setiap tahun di US. ${ }^{1}$

Takikardia ventrikel sering terjadi pada pasien dengan kardiomiopati atau bila terdapat parut dalam jantung. Pada pasien dengan penyakit jantung koroner (PJK), parut terjadi akibat infark miokard. Parut 
akan mengganggu impuls listrik normal pada jantung dan menghasilkan sirkuit pendek dari irama, yang disebut reentry. ${ }^{1}$

Terdapat tiga pilihan untuk penanganan TV, yaitu: implantable cardioverter defibrillator (ICD), obat antiaritmia, atau ablasi kateter. Pada sebagian kasus diperlukan kombinasi terapi. Pada pasien yang berisiko terjadinya TV, terapi ICD sangat efektif untuk mengembalikan denyut jantung ke irama normal. ${ }^{1,2}$ Connolly et al mendapatkan $28 \%$ penurunan kematian pada pengguna ICD dibandingkan dengan yang diobati dengan amiodaron. ${ }^{3}$ Walaupun ICD telah menjadi terapi utama untuk pencegahan sudden cardiac death namun ICD tidak dapat mencegah terjadinya $\mathrm{TV},{ }^{1,2,4}$ malah menciptakan kelompok pasien aritmia ventrikular dengan kualitas hidup yang menurun dan mortalitas yang meningkat. ${ }^{1,2}$ Hal ini disebabkan karena susbtrat aritmogenik tetap ada dan tidak berubah atau malah berkembang dan menghasilkan episode TV yang sering meningkat. ${ }^{2,5}$

Penggunaan ICD dapat mengakhiri episode TV dan menurunkan risiko sudden cardiac death, namun kejadian TV rekuren ditemukan pada 40-60\% pasien pengguna ICD setelah episode spontaneus sustained ventricular tachycardia. Episode pertama TV terjadi pada $20 \%$ pasien 3-5 tahun setelah implantasi ICD. ${ }^{4}$

Pemberian obat antiaritmia dengan ammiodaron atau sotalol dapat menurunkan episode TV dan menekan risiko rekurensi sampai $75 \%{ }^{2,4}$ Connoly et al mendapatkan bahwa kombinasi $\beta$-blocker dan amiodaron dapat menurunkan kejadian ICD shocks, ${ }^{6}$ namun akibat efek sampingnya maka amidaron harus dihentikan pada 25\% kasus. ${ }^{1}$

Metode pemetaan dan ablasi kateter telah berkembang pesat dalam dua dekade terakhir. ${ }^{1,2}$ Awalnya ablasi kateter hanya merupakan salah satu pilihan untuk pasien dengan TV fokal tanpa gangguan struktural jantung namun dewasa ini prosedur ablasi telah menjadi strategi pengobatan pilihan baik pada pasien dengan TV iskemia maupun non-iskemia. ${ }^{5}$ Pada TV rekurens akibat PJK yang sering merupakan kegawatdaruratan elektrofisiologi, ablasi kateter dapat mengontrol kejadian TV rekuren dan eliminasi TV jangka panjang, ${ }^{2,7-9}$ serta life-saving pada incessant TV. ${ }^{4,5}$

Perkembangan teknik ablasi TV dengan 3D mapping elektroanatomik sistem CARTO dapat melokalisasi substrat aritmogenik secara lebih akurat dan dapat dilakukan pada saat aritmia sedang berlangsung. Pemahaman yang baik mengenai pemicu dan substrat pada TV mengarahkan ke strategi ablasi baru yang memperluas indikasi ablasi TV. ${ }^{5,10}$ Dewasa ini, sebagian besar substrat aritmogenik ventrikel dapat ditangani dengan pendekatan ablasi kateter. ${ }^{5}$

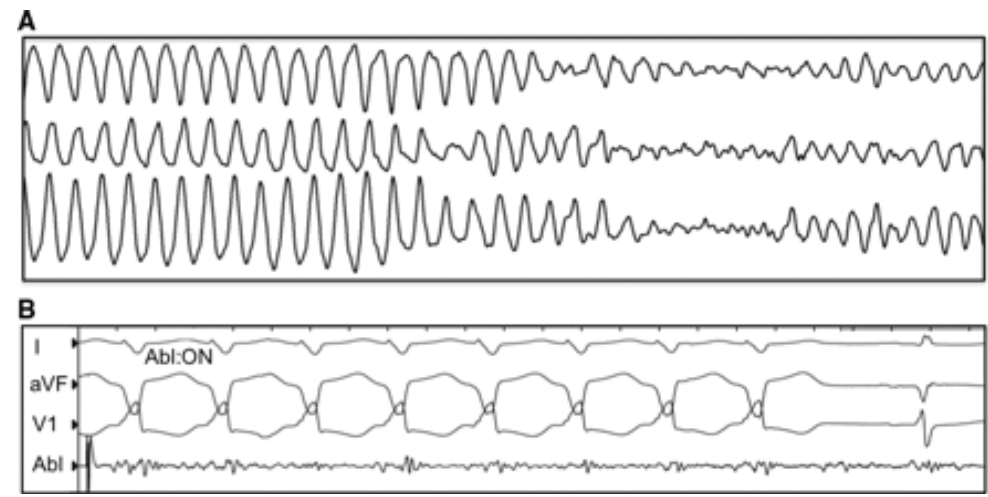

Gambar 1. A, TV sering beralih menjadi fibrilasi ventrikel. B, Ablasi pada TV. Ablasi radiofrekuensi dilepaskan (Abl:ON) pada tempat yang ditentukan dengan pemetaan. TV berhenti setelah 2 detik diablasi, dan irama jantung normal dipulihkan. Sumber: Tung et al, $2010 .{ }^{1}$ 


\section{TAKIKARDIA VENTRIKEL}

Takikardia ventrikel merupakan komplikasi yang sering dari PJK yang berperan penting dalam kejadian morbiditas dan mortalitas. Terdapat beberapa klasifikasi TV, yaitu: menurut gambaran EKG, mekanisme terjadinya TV, dan adanya substrat. ${ }^{5,8,11}$

\section{Klasifikasi TV menurut gambaran EKG}

Tampilan TV pada EKG sering menggambarkan penyebab dan menyertai penyakit jantung (Gambar 2). Terdapat tiga bentuk yang umum dari tampilan TV pada EKG, yaitu TV monomorfik, pleiomorfik, dan polimorfik. ${ }^{2,4}$

TV monomorfik mempunyai kompleks QRS yang sama pada setiap denyutan yang menunjukkan aktivasi ventrikel berulang dari substrat struktural atau fokus yang dapat menjadi target ablasi. Rangkaian depolarisasi ventrikel sama untuk setiap denyut. Umumnya disebabkan oleh reentry melalui daerah parut ventrikel. Morfologi QRS TV ditentukan oleh lokasi parut dan lokasi reentry di dalam parut, khususnya daerah exit dimana gelombang reentry menyebar dari parut untuk depolarisasi ventrikel. $^{4,12}$ Daerah parut sering memperlihatkan heterogenitas jaringan terutama pada border zone dengan nekrosis yang diantarai miosit yang viable (berfungsi). Perubahan pada densitas atau distribusi taut rekah (gap junction), terpisahnya berkas miosit yang viable oleh jaringan ikat, dan destruksi awal diikuti regenerasi saraf simpatis; kesemuanya mengambil bagian dalam terjadinya aritmia. $^{11}$

Berbagai morfologi TV dapat diinduksi pada pasien yang sama. Demikian pula berbagai TV dapat menggunakan ismus yang sama dengan exit berbeda, atau ismus yang berbeda pada parut yang sama, atau mengindikasikan adanya sirkuit reentry yang berbeda pada beberapa daerah berbeda dari parut (Gambar 2, 3). ${ }^{2,4,12}$

TV pleiomorfik mempunyai lebih dari satu kompleks QRS yang jelas yang terjadi pada episode TV yang sama, tetapi QRS tidak berubah secara kontinu. Pada beberapa pasien, satu TV monomorfik dapat mengawali TV monomorfik ke-2 yang menyebabkan $>1$ konfigurasi QRS yang nyata selama satu episode tunggal TV. ${ }^{2,12}$

TV polimorfik memperlihatkan konfigurasi QRS yang berubah-ubah pada setiap denyutan yang menunjukkan rangkaian aktivasi ventrikel yang berubah-ubah, dapat disebabkan oleh reentry fungsional tanpa target struktural untuk ablasi, antara lain pada iskemia miokard, acquired long QT syndrome, dan sejumlah sindroma genetik (Gambar 2). Kadang-kadang ablasi fokus awal dilakukan untuk mengontrol episode yang sering terjadi. ${ }^{2,4,12}$ Oleh karena TV polimorfik tidak sering mempunyai substrat yang dapat diidentifikasi menjadi target ablasi maka TV jenis ini memerlukan cara terapi dan diagnosis yang berbeda. EKG TV spontan sangat membantu evaluasi dan terapi. Dokumentasi TV klinis spontan pada 12 sadapan sangat dibutuhkan.

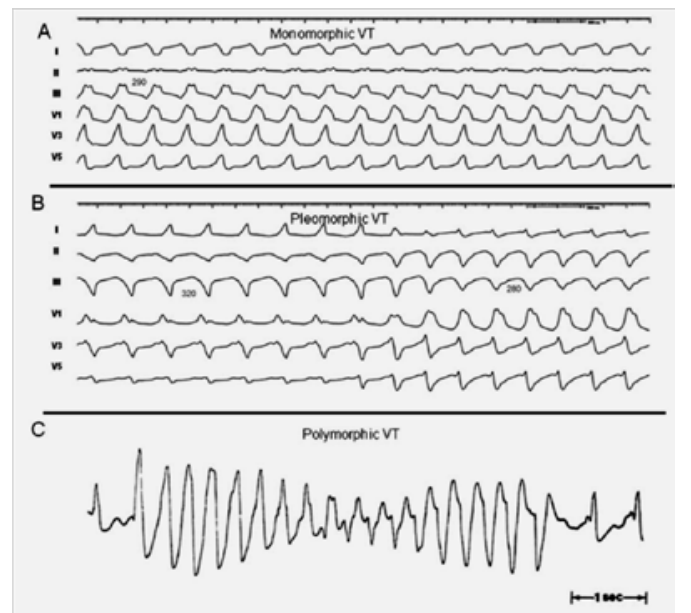

Gambar 2. Takikardia ventrikel. A, monomorfik; B, Pleomorfik; C, Polimorfik. Sumber: Aliot EM et al, 2009.

\section{Klasifikasi TV menurut mekanisme atau substrat $^{5}$}

Klasifikasi yang berkenaan dengan mekanisme TV, yaitu:

- TV idiopatik pada struktur jantung 
normal (right or left nonreentrant outflow tract tachycardia, left ventricular 'verapamil-sensitive' reentrant tachycardia)

- Bundle branch reentrant tachycardia

- TV yang berhubungan dengan penyakit jantung iskemik (PJK/infark miokard)

- $\quad$ TV pada penyakit jantung non-iskemik (idiopathic dilated CMP, arrythmogenic cardiomyopathy, setelah tindakan pembedahan pada kasus tetralogi Fallot, distrofi muskular atau penyakit neuromuskular)

- TV pada channelopathies (acquired long QT syndrome, sindrom Brugada, TV katekolaminergik)

Substrat turut berperan penting dalam menentukan mekanisme yag terjadi. Terdapat tiga jenis substrat yang diketahui, yaitu: ${ }^{5}$

1. Serat tunggal di dekat atau di atas katup ventrikel (terutama merupakan tempat asal idiopathic nonreentrant ventricular arrythmia)

2. Aritmia fasikular yang melibatkan bagian spesifik dari sistem konduksi. Aritmia yang terutama ialah jenis monomorfik (verapamil-sensitive idiopathic left ventricular tachycardia dan bundle branch reentrant tachycardia)

3. Scar-related TV yang berasal dari daerah bervoltase rendah dengan tanda anisotropik dan konduksi terlambat. Biasanya berhubungan dengan penyakit jantung struktural.

\section{PEMETAAN PADA TV}

Pada ablasi TV perlu dipertimbangkan apakah substrat yang mendasari itu tetap atau berubah secara dinamis. Ablasi TV fokal tanpa adanya parut ditargetkan di dekat katup dimana fungsi pompa jantung kurang berperan. Hal ini juga berlaku pada sebagian TV fokal dengan penyakit jantung iskemik. Ablasi fokus pada dinding ventrikel yang bebas atau muskuli papilaris tanpa adanya parut harus dilakukan dengan sangat hati-hati. ${ }^{5}$
Scar-related reentrant TV tergantung pada konduksi yang terlambat di area jaringan parut miokard dan ablasi terutama ditujukan pada jaringan parut (biasanya pada border zone dari area voltase rendah) sebelum ablasi dicoba pada jaringan sehat. Walaupun pemetaan voltase diterima sebagai pemetaan jaringan parut, perlu diperhatikan bahwa viabilitas listrik tidak identik dengan viabilitas miosit jantung. Pada keadaan iskemia dan inflamasi, voltase yang turun dapat reversibel. Adanya berbagai jenis TV ventrikel kanan, area voltase rendah pada ventrikel kanan atau terbukti TV reentrant perlu dicurigai adanya kardiomiopati ventrikel kanan yang aritmogenik. $^{5}$

Pemilihan tehnik pemetaan pada pasien TV tergantung pada mekanisme aritmia dan saat pemetaan harus dilakukan (irama sinus atau selama TV). Pemetaan selama TV membutuhkan inducibility TV dan toleransi hemodinamika. Pemetaan pada TV idiopatik berbeda dengan TV akibat parut. Pada TV idiopatik, target ablasi ke fokus aritmia yang jelas tanpa abnormalitas anatomi atau elektrofisiologi. Pada TV akibat parut, target ablasi ialah zona dengan konduksi lambat (ismus). Zona ini bisa ditentukan secara anatomi selama irama sinus walaupun partisipasinya pada sirkuit TV harus dibuktikan selama TV dengan menggunakan pemetaan langkah (pace mapping). ${ }^{13}$

Pemetaan ventrikel kanan harus dilakukan dengan hati-hati oleh karena adanya muskuli trabekularis yang besar dan volum ventrikel yang sempit. Pemetaan ventrikel kiri yang merupakan ruang jantung dengan kontraksi paling kuat dapat melalui beberapa pendekatan, yaitu: retrograd melalui katup aorta, elektroda pemetaan epikard yang dimasukkan melalui sinus koronarius, melalui epikardial setelah pungsi perikard, atau pendekatan transseptal. Pendekatan transseptal terutama dilakukan bila stenosis katup aorta jelas atau adanya katup aorta prostetik. ${ }^{5}$

Pada TV dengan hemodinamika stabil, pemetaan dapat dilakukan selama TV. Sering juga ditemukan pasien penyakit 
jantung dengan TV yang tidak dapat dipetakan atau tidak stabil karena TV perlu diterminasi segera akibat intoleransi hemodinamika, TV yang tidak dapat diinduksi, atau TV yang berubah-ubah. Pemetaan substrat (substrate mapping) atau pemetaan elektroda (electrode mapping) dikembangkan untuk menuntun ablasi pada TV jenis ini. ${ }^{4}$

Sirkuit akibat parut sering berukuran besar. Ablasi ditargetkan pada ismus dan eksit dari sirkuit reentry. Identifikasi dan penentuan target difasilitasi oleh pemetaan yang menghasilkan rekonstruksi 3 dimensi yang akurat dari anatomi jantung. Posisi kateter dapat dilacak pada peta yang mengurangi penggunaan fluoroskopi. Gambaran amplitudo elektrogram atau penentuan waktu dapat dikode dengan warna dan ditampilkan pada peta. ${ }^{2,4}$

Pada TV yang non-incessant, terutama bila induksi TV tidak stabil, pemetaan awal difokuskan pada substrat miokard abnormal selama irama sinus stabil (pemetaan substrat). Pada TV yang stabil, pemetaan dilakukan saat TV untuk menentukan ismus dan eksit dari sirkuit reentry dengan pemetaan aktivasi dan entrainment. Pemetaan substrat juga sering dilakukan bersamaan untuk meminimalisasi waktu TV serta mengurangi kebutuhan kardioversi dan gangguan hemodinamika. ${ }^{2}$

\section{PEMETAAN PADA TV AKIBAT PARUT}

Tehnik pemetaan voltase, aktivasi, entrainment, dan pacing umum digunakan pada TV akibat parut. Area parut dengan elektrogram beramplitudo rendah dapat diidentifikasi dengan pemetaan voltase selama irama sinus. Pemetaan aktivasi dan entrainment berfungsi untuk mengindentifikasi bagian kritis dari sirkuit reentrant selama TV yang diproteksi oleh perbatasan anatomi seperti parut dan struktur parut (ismus TV). ${ }^{12,13}$

\section{Pemetaan aktivasi (activation mapping)}

Pemetaan jenis ini direkomendasi untuk mendapatkan perjalanan arus listrik dengan membandingkan waktu aktivasi lokal dari beberapa titik (pre-selected point of reference). Sistem pemetaan elektroanatomikal CARTO dapat menghasilkan reproduksi 3 dimensi dari perjalanan stimulus listrik di miokard ventrikel dengan membatasi waktu aktivasi spesifik untuk setiap titik pilihan dan mengonversi data aritmatik ke peta berwarna. Peta ini dapat memberikan pemahaman mekanisme dan sirkuit TV yang lebih baik. Pemetaan nonkontak memungkinkan perekaman stimuli dari banyak titik dan sangat bermanfaat dalam reproduksi peta aktivasi selama hemodinamik yang tidak stabil atau nonsustained $\mathrm{TV} .^{12,13}$

Pemetaan aktivasi selama TV harus menggunakan kompleks QRS dengan defleksi yang paling tajam sebagai referensi untuk penghitungan waktu aktivasi elektrogram lokal. Pada kasus dengan elektrogram diastolik yang rumit, defleksi yang paling tajam harus dilacak secara independen terhadap amplitudo. ${ }^{5}$

TV monomorfik akibat parut biasanya merupakan TV re-entrant. Pemetaan ditujukan ke daerah ismus atau eksit dari stimulus pada miokard ventrikel. Ismus dihasilkan selama TV dengan potensial mid-diastolik di antara 2 kompleks QRS. Potensial presistolik yang mendahului kompleks QRS menghasilkan eksit sirkuit TV. Walaupun demikian, kontribusi nyata dari potensial-potensial ini terhadap sirkuit TV harus ditegaskan dengan pemetaan entrainment. ${ }^{13}$

\section{Pemetaan entrainment standar (standard entrainment mapping)}

Pemetaan entrainment sangat membantu pemetaan aktivasi pada TV re-entry. Limitasi dasar pemetaan ini ialah bila TV klinis tidak dapat diinduksi atau kurang ditoleransi secara hemodinamika. Pemetaan entrainment terdiri dari pengesetan kembali yang kontinu dari sirkuit TV dengan menampilkan overdrive pacing 20-30 ms lebih cepat daripada panjang siklus takikardi. Pada evaluasi pemetaan, takikardi harus dipercepat untuk sementara 
waktu sesuai dengan panjang siklus pacing kemudian bila memungkinkan untuk kembali ke panjang siklus semula setelah penghentian pacing. Ada tidaknya fusi (perubahan morfologik kompleks QRS) selama pacing dan durasi post-pacing interval (PPI) pada tempat stimulasi harus dianalisis dengan cermat. ${ }^{13}$

Kriteria entrainment standar dapat membuktikan adanya elektrogram kritikal di dalam sirkuit reentrant. Pemetaan entrainment dilakukan selama TV dengan panjang siklus $10 \%$ lebih pendek. Entrainment positif bila: 1) Paced QRS identik dengan QRS TV; 2) stimulus ke interval QRS kurang lebih sama dengan interval onset elektrogram QRS saat TV; dan 3) pacing pada tempat memperlihatkan panjang siklus balik menyerupai panjang siklus TV $( \pm 30 \mathrm{~ms}){ }^{13}$

\section{Pemetaan substrat (substrate mapping)}

Pemetaan substrat sangat membantu pemetaan aktivasi dan entrainment pada TV akibat parut. Pemetaan jenis ini direkomendasikan untuk mengidentifikasi substrat anatomik yang dapat mengarahkan ke TV (parut dan zona konduksi lambat) melalui tampilan pemetaan 3 dimensi berwarna dari ventrikel kiri yang merekam amplitudo potensial elektrogram lokal selama irama sinus. ${ }^{2,13}$ Pemetaan substrat dapat mencakup pemetaan voltase dan pacing. $^{2}$

Terdapat klasifikasi zone infark dan area parut padat melalui pemetaan voltase bipolar. Jaringan yang berhubungan dengan parut mempunyai voltase bipolar rendah $\leq 1,5 \mathrm{mV}$ diukur dari amplitudo puncak-kepuncak (peak-to-peak) elektrogram (diperoleh dengan 7F mapping catheter $4 \mathrm{~mm}$ tip electrode). Daerah dengan potensial rendah $<1,5 \mathrm{mV}$ ditetapkan sebagai parut sedangkan daerah dengan potensial $<0,5$ $\mathrm{mV}$ ditentukan sebagai parut padat. ${ }^{2,5,13}$ Kriteria ini telah dipergunakan secara luas untuk pemetaan voltase. Disamping merekam potensial selama irama sinus, batas anatomi diidentifikasi dengan bantuan sistem pemetaan elektro- anatomikal. Bila ismus dengan konduksi lambat selama periode diastolik atau presistolik teridentifikasi pada area voltase rendah, ablasi linear sering berhasil. ${ }^{5}$

Parut yang tidak dapat dieksitasi (inexcitable scar) dapat diidentifikasi selama TV dan irama sinus. Pada pasien pasca infark, TV yang dapat ditoleransi diperkirakan mempunyai ukuran sirkuit $>3$ $34 \mathrm{~cm}$. Bagian tengah ismus dan jalan masuk (entrance site) khas terletak dalam parut infark miokard yang padat sedangkan tempat eksit dari sirkuit reentrant terletak pada zona perbatasan (border zone) dari area bervoltase rendah (Gambar 3). ${ }^{5}$

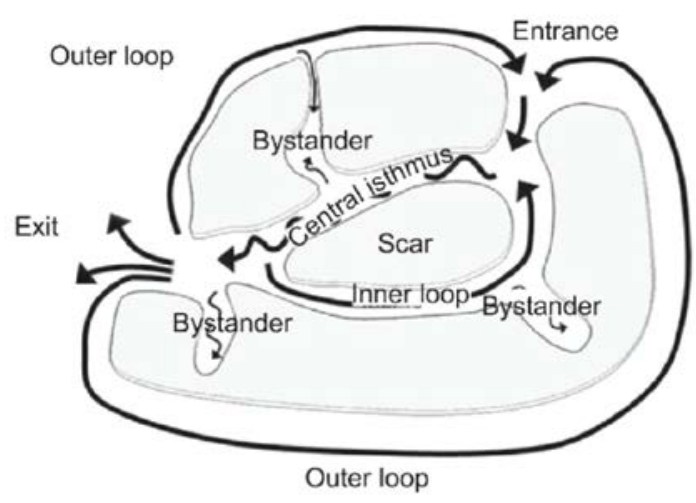

Gambar 3. Model anatomik dari sirkuit reentry untuk menjelaskan TV pasca infark miokard. Sumber: Benito B dan Mark E Josephson ME, 2012. ${ }^{14}$

Pada TV yang dapat diinduksi (inducible) dan stabil, pemetaan entrainment dilakukan bersamaan dengan pemetaan substrat untuk membatasi jumlah lesi ablasi. Banyak strategi ablasi menargetkan substrat anatomik TV melalui pembuatan lesi linear yang melintasi ismus. Ablasi dapat dituntun oleh pemetaan substrat saja tetapi sering mengidentifikasi daerah parut dan sirkuit reentry yang relatif lebih besar. Kombinasi pemetaan substrat dengan episode singkat pemetaan aktivasi dan entrainment bahkan pada pasein dengan TV tidak stabil dapat meningkatkan keberhasilan ablasi TV. ${ }^{2}$ 


\section{Pemetaan langkah (pace mapping)}

Pemetaan langkah terdiri dari stimulasi beberapa daerah berbeda selama irama sinus untuk membandingkan morfologi kompleks QRS yang terstimulasi dengan morfologi TV klinis. Pemetaan ini sangat bermanfaat untuk menentukan lokasi asal dari TV fokal, terutama bila hanya sedikit ekstrasistol ventrikel yang terekam atau bila TV klinis tidak dapat diinduksi, namun pemetaan ini lebih kurang akurat daripada pemetaan aktivasi. ${ }^{13}$

Pemetaan langkah dapat membantu pemetaan substrat untuk menentukan zona refakter listrik yang mungkin membatasi zone ismus dan zona eksit pada zona perbatasan dari parut yang memperlihatkan morfologi QRS serupa TV klinis dengan interval QRS stimulus pendek (short stimulus QRS interval). Pemetaan ini dapat membantu menentukan daerah exit dari TV. Berbeda halnya dengan pemetaan langkah untuk ablasi TV idiopatik, pada TV reentrant akibat parut pemetaan ini hanya memberikan perkiraan sirkuit TV. ${ }^{13}$

\section{Pemetaan saat takikardia ventrikel}

Pada TV dengan hemodinamika stabil, pemetaan dapat dilakukan saat takikardia. Peta rangkaian aktivasi dibuat melalui penandaan waktu elektrogram relatif terhadap onset QRS. Eksit dan ismus pada sirkuit reentry dipolarisasi sebelum onset QRS untuk memberikan elektrogram presistolik atau diastolik. Elektrogram yang serupa juga dapat direkam dari bystander yang tidak merupakan bagian integral dari sirkuit. Pengenalan ismus diperoleh melalui efek pacing pada tempat saat TV (pemetaan entrainment). Ismus juga dapat dikenal melalui tekanan mekanis simpel dari kateter mengakhiri TV atau stimulus yang tidak muncul untuk menangkap terminasi TV. ${ }^{2}$

\section{ABLASI PADA TV}

\section{Pre-prosedur}

- Ekokardiografi atau special imaging dengan CT scan harus dilakukan pada semua pasien yang direncanakan ablasi untuk melihat adanya trombus ventrikel kiri yang mobile, menentukan letak parut, dan menilai fungsi pompa jantung. Bila dicurigai adanya laminated thrombus, harus diberikan antikoagulan warfarin selama beberapa minggu untuk mencegah terjadinya trombus bebas. ${ }^{1,2,4}$

- Ekokardiogram transesofageal dilakukan untuk mengeksklusi adanya bekuan darah di dalam jantung. ${ }^{1}$

- Angiografi koroner harus dilakukan bila status vaskular koroner tidak diketahui atau pada kasus TV polimorfik. Adanya PJK yang tidak diobati akan membatasi mapping saat TV karena masalah hemodinamik akibat iskemi miokard. ${ }^{2}$

- Anestesi umum harus dilakukan bila TV dengan hemodinamik tidak stabil atau diantisipasi akan terjadi. Perbaikan hemodinamik akan memfasilitasi pemetaan dan ablasi serta menurunkan risiko gangguan hemodinamik dari episode TV saat dilakukan prosedur. ${ }^{2}$ Selama pemetaan ventrikel kiri dan ablasi, diberikan antikoagulan sistemik heparin intravenosa. Setelah ablasi, antikoagulan aspirin atau warfarin direkomendasikan selama sebulan tergantung pada ablasi yang dilakukan untuk mencegah terbentuknya bekuan darah selama proses penyembuhan. Short acting low-molecular-weight heparin diberikan pada beberapa hari pertama oleh karena warfarin memerlukan 5-10 hari untuk bekerja efektif. $^{1}$

\section{Tehnik ablasi}

Arus radiofrequensi (RF) cukup aman dan praktis sehingga dipakai sebagai energi ablasi. ${ }^{1,2}$ Elektroda padat 4 atau $5 \mathrm{~mm}$ digunakan untuk TV idiopatik tetapi untuk scar-related TV sering diperlukan aplikasi RF berulang serta lesi yang lebih besar dan dalam dengan dibantu oleh irrigated $R F$ ablation atau elektroda yang lebih besar (8 $\mathrm{mm})$.

Langkah-langkah tindakan ablasi yaitu: setelah akses vaskular diperoleh, aritmia 
diinduksi untuk menegakkan diagnosis dan menentukan apakah penghentian inducible TV merupakan endpoint dari prosedur. Pemetaan dilakukan untuk menentukan lokasi sumber TV diikuti ablasi. Pengujian dilakukan untuk melihat efek ablasi. ${ }^{4}$

Stimulasi terprogram dilakukan untuk menginduksi TV, menegakkan diagnosis, mendapatkan morfologi EKG dari TV, dan menentukan apakah TV non-inducibility dapat menjadi acute procedural endpoint. Dalam hal TV non-klinis non-inducibility atau inducibility, pemetaan substrat dilakukan dan ablasi menjadi pilihan. Bila TV disertai hemodinamik tidak stabil, harus segera diakhiri dengan burst pacing atau kardioversi elektrik. Berdasarkan lokasi parut dan morfologi TV, pemetaan dilakukan pada ventrikel kanan, ventrikel kiri atau perikard. ${ }^{2}$

\section{Pemetaan dan penentuan ablasi TV endokard dan epikard}

Pada pemetaan endokard, akses ke ventrikel kiri sering diperoleh secara transseptal atau retrograd melalui katup aorta. $^{2,4}$ Kerusakan katup aorta atau ostia arteri koronaria bisa terjadi walaupun jarang. Komplikasi akses vaskular yang signifikan termasuk diseksi arteri, perdarahan, fistula atriventrikular femoral dilaporkan terjadi pada 2,1\% pasien pada satu studi multisenter. Pendekatan transseptal ke atrium kiri memberikan akses ke ventrikel kiri melalui katup mitral pada pasien dengan penyakit pembuluh darah perifer, katup aorta mekanis, atau untuk insersi kateter pemetaan multipel. Emboli sitemik atau serebral dilaporkan terjadi $0-2,7 \%$ kasus. $^{4}$

Pemetaan endokard LV bisa dilakukan transseptal atau retrograd. Sampai saat ini belum ada studi yang membandingkan transaortik retrograd dan transseptal anterograd untuk pemetaan dan ablasi $\mathrm{LV}^{2}$ Kegagalan ablasi endokard meningkatkan kecurigaan substrat epikard terutama adanya gambaran EKG spesifik. ${ }^{13}$

Pemetaan epikardial dan ablasi sering dilakukan bila dicurigai adanya TV epikardial. Akses ke epikard diperoleh melalui pungsi perikard dari bawah os sifoid. Pada pasien dengan adhesi perikard sering tidak dapat digunakan akses epikardial perkutan; dalam hal ini diperlukan tindakan pembedahan untuk ablasi. $^{1,2}$ Steroid diberikan untuk menghindari terjadinya perikarditis steril (11\%). ${ }^{2}$ Sarkozy et al melaporkan bahwa ablasi epikardial bermanfaat pada $\geq 6 \%$ populasi TV pasca infark. Jumlah tersebut diprediksikan bisa lebih tinggi karena 2/3 dari pasien yang diseleksi untuk pemetaan epikard setelah kegagalan ablasi memperlihatkan target TV epikardial. ${ }^{15}$

Pendekatan epikardial untuk ablasi ventrikel dilakukan pada:

1. Ablasi endokard gagal, antara lain pada TV yang berasal dari intramural yang dalam atau epikard ${ }^{4}$

2. Kontraindikasi terhadap pemetaan endokardial (katup prostetik aorta atau mitral) $)^{13}$

3. EKG mengarahkan ke asal TV epikardial $^{13}$

\section{ABLASI PADA TV AKIBAT PARUT}

Rerentry akibat parut merupakan penyebab utama TV monomorfik yang menetap (sustained monomorphic). ${ }^{4,5,13}$ Penyebabnya mencakup infark miokard, kardiomiopati, dan insisi pembedahan. Area parut miokard biasanya terdiri dari daerah-daerah padat berupa fibrosis interstitial yang inexcitable yang berkerja sebagai sawar konduksi (conduction barrier), dan daerah miokard dengan miosit yang bertahan hidup (surviving) yang menjadi koridor untuk reentry. Ismus terdiri dari massa kecil jaringan. Depolarisasi dalam ismus menghasilkan sinyal beramplitudo rendah yang tidak berkontribusi ke kompleks QRS pada EKG permukaan. Kompleks QRS tercatat bila gelombang eksitasi keluar dari eksit sepanjang perbatasan parut dan menyebar ke ventrikel. Keluarnya aktivasi dari saluran ini ke miokard sekitarnya akan menentukan morfologi QRS karena semua miokard yang viable diaktivasi dari titik ini. 
Daerah proksimal terhadap tempat keluar merupakan daerah sentral atau proksimal. Setelah meninggalkan tempat keluarnya, gelombang eksitasi terdepan dapat kembali ke daerah proksimal melalui zona yang luas dari miokard sepanjang perbatasan parut (lengkung luar, outer loop) sedangkan lengkung dalam (inner loop) terdapat di dalam parut. Tempat yang tidak menjadi reentry disebut bystanders (Gambar 3). ${ }^{4,5}$

Konfigurasi sirkuit reentry dan lokasinya bervariasi dari pasien ke pasien. Parut yang menyebabkan TV sering membatasi anulus katup yang membentuk segmen tepi dari bagian sirkuit reentry. Stimulasi terprogram yang berulang menginduksi $>1$ TV monomorfik. TV multipel dapat disebabkan oleh sirkuit berbeda pada area yang berjauhan dari parut, exit berbeda pada parut yang sama, atau perubahan aktivasi sirkuit oleh blok fungional. Ablasi pada satu daerah sering dapat menghilangkan $>1 \mathrm{TV} .{ }^{4}$ Penggunaan 12-lead ECG dapat membantu melokalisasi tempat eksit TV dari sirkuit reentrant. ${ }^{5}$

Ablasi ditargetkan ke ismus (zona konduksi lambat) yang biasanya terletak di dalam parut dan berperan dalam mempertahankan sirkuit reentry. Cara terbaik untuk menentukan lokasi ismus ialah dengan menggunakan pemetaan aktivasi atau entrainment, dan juga substrat. Pada prinsipnya ablasi bertujuan untuk mengeliminasi TV klinis dan bukan berbagai TV non-klinis yang terjadi selama prosedur. Pemakaian cooled tip catheter yang membuat lesi lebih besar dan dalam menjadi pilihan pada jenis TV ini. Adanya sirkuit epikardial harus selalu dipertimbangkan oleh karena dapat dijumpai pada $10-30 \%$ TV. $^{13}$

\section{Point (focal) ablation for stable reentrant TV}

Stevenson et al. membagi ismus konduksi lambat dari takikardia pasca infark menjadi ismus eksit, sentral dan proksimal. Batas anatomi tidak harus sesuai dengan gambaran tersebut. Model ini bermanfaat untuk konsep penemuan selama pemetaan dan ablasi TV dengan hemodinamika yang dapat ditoleransi. Penemuan yang terpenting ialah interval postpacing \pm 30 ms dari panjang siklus TV dengan fusi tersembunyi berhubungan dengan terminasi takikardia oleh ablasi RF (solid $4 \mathrm{~mm}$ tip catheter) dan keberhasilan paling tinggi pada tempat eksit dari ismus. ${ }^{5}$ Limitasi terpenting dari single point ablation ialah jumlah rendah (sekitar 10\%) pasien pasca infark dengan well-tolerated sustained TV yang dapat terjadi melalui induksi oleh stimulasi terprogram. Pada pasien dengan riwayat TV yang ditoleransi baik, keberhasilan ablasi sekitar 58\%. ${ }^{5}$

Pendekatan ablasi fokal yang menargetkan aktivasi endokard yang terdini atau hanya satu point positive entrainment tanpa pemahaman ismus konduksi kritikal lengkap sering bermanfaat untuk terminasi TV yang menetap. Walaupun demikian, keberhasilan jangka panjang tidak jelas bahkan bila TV yang ditargetkan noninducible pada akhir prosedur. Data pasien pasca infark setelah ablasi lokal memperlihatkan rekurensi TV yang tinggi (70\%) selama kontrol jangka panjang pada TV klinis dan nonklinis, bahkan pada kasus yang tidak dapat diinduksi pada akhir studi elektrofisiologi. Ablasi ismus linear mempunyai rekurensi TV yang lebih rendah (30\%) dan cara ini lebih disukai. Bila tidak terdapat ismus konduksi diastolik yang dapat ditentukan, substrate-based ablation dengan tuntunan kriteria potensial atau voltase sebaiknya dilakukan untuk menurunkan rekurensi TV. ${ }^{5}$

\section{Substrate-based ablation of scar related TV}

Tehnik ablasi ini digunakan untuk bentuk TV unstable dan juga bermanfaat pada kasus TV noninducible atau polimorfik. Dewasa ini substrate-based ablation telah digunakan sebagai bagian dari tindakan rutin untuk hampir semua pasien dengan ablasi TV. ${ }^{5}$

Substrate-based ablation berdasarkan pada pemetaan elektroanatomik yang rinci selama irama sinus atau paced rhythm dan dapat menentukan daerah eksit dari TV dengan pemetaan langkah untuk dokumen- 
tasi TV. Hasil pemetaan langkah harus diinterpretasi dengan hati-hati dan berpatokan pada karakteristik substrat. Bila tidak terdapat tempat matching dari pace map, perkiraan yang mendekati akan bermanfaat untuk guide ablation. ${ }^{5}$

\section{KOMPLIKASI ABLASI PADA TV}

Ablasi kateter pada TV merupakan prosedur invasi yang rumit dengan berbagai risiko yang berat terutama pada kasus dengan penyakit jantung struktural yang lanjut. Komplikasi berat ditemukan pada 8\% kasus dengan penyakit lanjut dan mortalitas 3\%. Komplikasi berat mengakibatkan rawat inap yang berkepanjangan, membutuhkan prosedur tambahan untuk pengobatan, atau berakibat kerusakan parah bahkan kematian. ${ }^{13}$

Komplikasi yang dapat terjadi ialah:

- Lesi vaskular di tempat perforasi (hematoma, arteriovenous shunt, pseudoaneurisma) ditemukan pada $2 \%$ kasus $^{13}$

- Tromboemboli dilaporkan pada $1,3 \%$ kasus. Penggunaan irrigated tip catheter dan antikoagulan selama tindakan dapat menurunkan risiko ini ${ }^{13}$

- Tamponade jantung dilaporkan pada $1 \%$ kasus $^{13}$

- Stroke pada $<1 \%$ kasus $^{1}$

- Ablasi epikard melalui akses perikardial dapat terjadi efusi perikardial (1-2\%), perdarahan epikardial (4,5\%), perdarahan yang memerlukan penanganan bedah $(<1 \%)$, laserasi hepar (3\%), dan cedera arteri koroner epikardial (1,2\%) yang dapat berakibat serangan jantung. Angiogram koroner perlu dilakukan untuk mengurangi risiko ${ }^{1,2,4}$

- Cedera nervus frenikus kiri: dapat dihindari dengan identifikasi melalui pacing dari kateter ablasi ${ }^{4}$

\section{KEBERHASILAN ABLASI PADA TV}

Keberhasilan tindakan ablasi TV tergantung pada penyebab TV. Tindakan ini lebih efektif pada pasien dengan kondisi jantung normal dengan keberhasilan $>90 \%$.
Pada pasien dengan penyakit jantung struktural akibat parut atau kardiomiopati keberhasilan ablasi sekitar 50-75\% dalam 6-12 bulan. Pada pasien dengan rekurensi, kejadian TV yang dialami lebih kurang daripada sebelum tindakan ablasi. ${ }^{1}$

Hasil dari dua prospective randomized trial SMASH-TV study dan TVACH terhadap outcome pasien penyakit jantung iskemia disertai TV yang dilakukan ablasi kateter menunjukkan bahwa ablasi dapat mencegah rekurensi TV dan menurunkan jumlah ICD shock. $^{2}$

Tanner et al. menggunakan teknologi kateter yang diirigasi dengan $\mathrm{NaCl}$ (open saline-irrigated catheter technology) dituntun oleh pemetaan elektroanatomikal pada infark miokard, baik pada pemetaan yang relevan maupun tidak, memperlihatkan keberhasilan tinggi dan komplikasi rendah namun masih dijumpai rekurensi. ${ }^{8}$ Bhargava et al. melaporkan kasus TV iskemik pada ventrikel kiri dengan pemetaan entrainment. Ablasi radiofrekuensi berhasil menghentikan TV dan memperlihatkan PPI yang lebih pendek daripada panjang siklus TV. ${ }^{16}$

Ablasi TV setelah infark miokard mempunyai keberhasilan awal 70-95\% dengan pemetaan substrat. TV terjadi kembali pada 20-50\% kasus walaupun pada mayoritas kasus frekuensi episode telah berkurang. Hasil studi memperlihatkan bahwa ablasi TV preventif berdasarkan substrat berhasil secara signifikan menurunkan jumlah pemakaian defibrilator selama follow up. Walaupun demikian, perbandingan keberhasilan dari berbagai studi perlu diteliti karena endpoint ablasi yang berbeda pada masing-masing studi. ${ }^{13}$

\section{SIMPULAN}

Takikardia ventrikel akibat parut merupakan komplikasi yang sering ditemukan pada PJK. Pemetaan aktivasi dan pemetaan langkah sangat bermanfaat pada mekanisme takikardia ventrikel fokal sedangkan pemetaan substrat (dengan atau tanpa pemetaan langkah) sedangkan pemetaan entrainment digunakan untuk 
mekanisme takikardia ventrikel reentrant.

Ablasi telah menjadi pilihan utama untuk kasus takikardia ventrikel dengan penggunaan ICD dan medikasi yang tidak efektif atau intoleransi namun sampai saat ini belum terdapat rekomendasi yang pasti mengenai strategi pemetaan dan teknik ablasi yang terbaik untuk TV akibat parut.

\section{DAFTAR PUSTAKA}

1. Tung R, Boyle NG, Shivkumar K. Catheter ablation of ventricular tachycardia. Circulation. 2010;122:e389-e391.

2. Wissner E, Stevenson WG, Kuck KH. Catheter ablation of ventricular tachycardia in ischaemic and nonischaemic cardio-myopathy: where are we today? A clinical review. Eur Heart J. 2012;33:1440-50.

3. Connolly SJ, Hallstrom AP, Cappato R, Schron EB, Kuck KH, Zipes DP, et al. Meta-analysis of the implantable cardioverter defibrillator secondary prevention trials. Eur Heart J. 2000;21:2071-78.

4. Stevenson WG, Soejima K. Catheter ablation for ventricular tachycardia. Circulation. 2007;115: 2750-60.

5. Schreieck J, Hessling G, Pustowoit A, Schmitt C. Vengtricular tachycardia. In: Schmitt C, Deisenhofer I, Zrenner B, eds. Catheter ablation of cardiac arrhythmias a practical approach. Darmstadt: Springer, 2006.

6. Connoly SJ, Dorian P, Roberts RS, Gent M, Bailin S, Fain ES, et al. Optimal pharmacology therapy in cardioverter defibrillator patients I. Comparison of beta-blockers, amiodarone plus betablockers, or sotalol for prevention of shocks from implantable cardioverter defibrillatoirs: the OPTIC study: a randomized trial. J Am Med Assoc. 2006;295:165-71.

7. Marchlinski F, Garcia F, Siadatan A, Sauer W, Beldner S, Zado E, et al. Ventricular tachycardia/ventricular fibrillation ablation in the setting of ischemic heart disease. J Cardiovasc Electrophysiol. 2005;16(1):S59-70.

8. Tanner H, Hindricks $G$, Volkmer $M$,
Furniss S, Kuhlkamp V, Lacroix D, et al. Catheter ablation of reccurent scarrelated ventricular tachycardia using electro-anatomical mapping and irrigated ablation technology: Results of the prospective multicenter Euro-TVStudy. J Cardiovasc Electrophysiol. 2010;21(1):47-53.

9. Reddy VY, Reynolds MR, Neuzil P, Richardson AW, Taborsky $M$, Jongnarangsin $\mathbf{K}$, et al. Prophylactic catheter ablation for the prevention of defibrillator therapy. $\mathrm{N}$ Eng $\mathrm{J}$ Med. 2007;357:2657-65.

10. Tadjoedin Y, Yuniadi Y, Firdaus I, Harimurti GM, Munawar M. Ablasi takikardia ventrikular dengan pemetaan elektro-anatomikal 3 dimensi. J Kardiol Ind. 2007;28:142-45.

11. Yen Ho, Ernst S. Anatomy of cardiac electrophysiologists a practical handbook. Minneapolis: Cardiotext, 2012.

12. Letsas KP, Charalampous $\mathrm{Ch}$, Weber $\mathbf{R}$, Tsikrikas S, Efremidis M, Arentz T, et al. Methods and indications for ablation of ventricular tachycardia. Hellenic J Cardio. 2011;52:427-36.

13. Sarkozy A, Tokuda M, Tedrow UB, Sieria J, Michaud GF, Couper GS, et al. Epicardial ablation of ventricular tachycardia in ischemic heart disease. Circ Arrhythm Electrophysiol. 2013;6(6):1115-22.

14. Benito B, Josephson ME. Ventricular tachycardia in coronary artery disease. Rev Esp Cardiol. 2012;65:939-55. DOI: 10.1016/j.rec.2012.03.022.

15. Bhargava K, Tomar HS, Gupta $P$, Singh B. Entrainment during ablation of ischemic ventricular tachycardia. What is explanation for post pacing interval shorter than the tachycardia cycle length? Indian Pacing and Electrophysiol J. 2011;11(6):167-68.

16. Aliot EM, Stevenson WG, AlmendralGarrote JM, Bogun F, Calkins H, Delacretaz E, et al. EHRA/HRS expert concensus on catheter ablation of ventricular arrhythmias. Europace. 2009;11:771-817. 